\title{
The effects of different doses of thymulin in vivo and in vitro on some biological properties of bone marrow-derived multipotent mesenchymal stromal cells in mice of different strains
}

\author{
Labunets I. F., Rodnichenko A. E. \\ State Institute of Genetic and Regenerative Medicine of the National Academy of Medical Sciences of Ukraine, Kyiv, Ukraine \\ e-mail: irina_labunets@ukr.net
}

\section{ABSTRACT}

A promising source for cell therapy are multipotent mesenchymal stromal cells (MMSC), whose biological properties can change at immune dysfunction of central genesis.

THE PURPOSE of the study is to investigate the ability of murine bone marrow-derived MMSC to colony formation, directed differentiation and immunosuppressive effect at different content of serum thymic factor (thymulin) in the body and in the cell culture in mice of different strains.

MATERIALS AND METHODS. MMSCs cultures were obtained from the bone marrow of FVB/N and 129/SV mice. We performed the study of clonogenic ability of MMSCs, phenotyping, assessment of the osteogenic and adipogenic potential, estimation of immunomodulating properties of MMSCs after thymectomy or addition of the thymulin in the culture in vitro.

RESULTS. It was found that the level of thymulin in the control mice of the FVB/N strain is higher than in 129/Sv mice. The ability of bone marrow progenitor cells to colony formation in control and thymectomized mice depends on their genotype. When adding thymulin at concentrations of $1 \mathrm{ng} / \mathrm{mL}$ and $10 \mathrm{ng} / \mathrm{mL}$ to the bone marrow cells culture of both strains thymectomized mice, the change in the number of colonyforming unit fibroblasts was observed only with the addition of a high dose of the hormone. Thymectomy in FVB/N mice leads to an increase in the differentiation of MMSCs in the osteogenic direction and to a decrease in adipogenic differentiation, which is restored after adding thymulin to the cell culture. In thymectomized 129/Sv mice, there was a decrease in osteogenic differentiation and recovery after incubation of cells with thymulin. The immunosuppressive effect of bone marrow MMSCs was established in mice of both strains. In this case, strain-dependent differences in this effect are manifested in the degree of immunosuppression.

CONCLUSION. The ability of bone marrow MMSC of the FVB/N and 129/Sv mice to colony formation, directed differentiation and immunosuppressive effect at different content of thymulin in the body or in cell culture is related with the thymus function and changes after thymectomy.

The response of the bone marrow MMSCs to the thymectomy depends on the genotype of the mice. It has been shown that thymulin has a recover effect on the reduced clonogenic and osteogenic potential of the bone marrow-derived MMSCs in mice of both strains and the adipogenic potential in 129/Sv mice.

KEY WORDS: bone marrow MMSCs; thymectomy; serum thymic factor; thymulin

Bone marrow-derived multipotent mesenchymal stromal cells (MMSCs) possess a wide spectrum of biological activity due to their ability to multilinear differentiation, trophic effects on damaged tissues, and immunomodulating properties [1]. That is why the MMSCs are promising for cell therapy of damage to various organs, increasing the survival rate of the transplanted allogeneic cells and reducing the risk of graft-versus-host disease [2-6].

The biological properties of the bone marrow-derived MMSCs may change under the influence of cellular and endocrine factors [7, 8]. Among the latter, the highly active thymus hormone thymulin or serum thymic 
factor, which affects the differentiation of T-lymphocytes in the thymus, their migration and function, is of interest [9-11]. We have shown the change in the colony-forming ability of the bone marrow-derived MMSCs during physiological variation of the thymulin level in the blood of $\mathrm{CBA} / \mathrm{Ca}$ mice and after the application of thymic bioactive factors [12]. The involvement of different subpopulations of T-lymphocytes in the realization of MMSCs function such as differentiation in the osteogenic direction and control of hematopoiesis $[13,14]$ does not exclude the possibility of the influence of thymic hormones on these properties of MMSCs.

One of the promising approaches to the study of the interactions of the thymus and the bone marrow-derived MMSCs can be the carrying out of experiments in mice of different strains. In the literature, there is evidence of the importance of taking into account the animal genotype in assessing metabolic changes, functioning of the immune, endocrine system and MMSCs in bone marrow $[15,16]$. The results of our previous studies showed that mice of different strains with models of thymus dysfunction differ in the ability to differentiate hematopoietic stem cells and proliferative potential of bone marrow-derived MMSCs $[10,17,18]$.

The purpose is to study the ability of murine bone marrow-derived MMSC to colony formation, directed differentiation and immunosuppressive effect at different content of serum thymic factor (thymulin) in the body and in the cell culture in mice of different strains.

\section{MATERIALS AND METHODS}

Animals. The studies were performed on 3-4 months old male FVB/N (genotype $\mathrm{H}-2 \mathrm{q}, \mathrm{n}=24$ ) and 129/Sv (genotype $\mathrm{H}-2, \mathrm{n}=24$ ) mice, keeping of the State Institute of Genetic and Regenerative Medicine NAMS Ukraine. The choice of these strains for research is explained by straindependent features of the functioning of the bone marrow, thymus and immune system $[15,17,18]$. Animals were at a 12:12 light:dark cycle and free access to water and food ad libitum. All works with experimental animals were carried out in compliance with the laws and principles of the «European Convention for the Protection of Vertebrate Animals used for Experimental and other Scientific Purposes» (Strasbourg, 1986), as well as the Law of Ukraine "On the Protection of Animals from Cruelty" (of 21.02. 2006).

Experimental groups of mice. The thymus dysfunction in mice was modelled by thymectomy under anesthesia $(2.5 \%$ avertin, $125 \mathrm{mg} / \mathrm{kg}$, intraperitoneally). Control group - sham-operated animals of both strains. Blood and tissue were obtained after decapitation of mice under ether anesthesia in the morning $(9.00-10.00) 4$ weeks after the operation.

Stages of the experiment. In experimental mice, the endocrine function of the thymus was assessed in vivo. In experiments in vitro, the clonogenic potential of bone marrow-derived cells was studied, the MMSCs phenotyping, the estimation of the osteogenic and adipogenic potential of MMSCs, the immunomodulating properties of MMSCs, and the possibility of the direct effect of thymulin on the biological properties of MMSCs of thymectomized animals were performed.

Endocrine function of the thymus was assessed by the level of thymulin in the blood [19]. The method is based on the ability of thymulin to restore azathioprine sensitivity of spontaneous rosette-forming spleen cells of adult thymectomized mice. For centrifugal ultrafiltration of animal serum we used Centriflo CF-50A (Amicon, USA) conical filters to eliminate the high-molecular-weight inhibitor of thymulin. The thymulin titer was the last serum dilution, which caused a $50 \%$ reduction in the number of rosette-forming spleen cells relative to the control. The results were expressed as $\log _{2}$ of the hormone titer. In thymectomized mice, the serum level of thymulin should be zero.

Bone marrow cells were obtained by flushing of the femurs by RPMI1640 medium (Sigma, USA). Cultivation was carried out in $25 \mathrm{~cm}^{2}$ culture flasks in the RPMI-1640 medium, supplemented with $10 \%$ fetal bovine serum (FBS), $2 \mathrm{mM} \mathrm{L-glutamine,} 100 \mathrm{U} / \mathrm{mL}$ penicillin, $100 \mu \mathrm{g} / \mathrm{mL}$ streptomycin (all - Sigma, USA).

Phenotyping of the bone marrow-derived MIMSCs was carried out using monoclonal antibodies against markers Sca-1, CD44, CD73, CD90, CD45 (Becton Dickinson, USA). Cell samples without antibodies (unstaining control) were used as negative control. The fluorescence was also analyzed in samples with each of the antibodies separately (single staining controls). The analysis was performed with cell sorter BD FACSAria (Becton Dickinson, USA).

The study of clonogenic potential of bone marrow cells. The bone marrow cells in monolayer cultures in vitro forms colonies, consisting of colony-forming units of fibroblasts (CFU-F) [20]. Bone marrow cells with a seed density of $2 \cdot 10^{5}$ cells $/ \mathrm{cm}^{2}$ were cultured in a complete medium containing $85 \%$ RPMI-1640, 15 \% FBS, 2 mM L-glutamine, (Sigma, USA) for 12 days at $37{ }^{\circ} \mathrm{C}$ in a humidified atmosphere containing $5 \% \mathrm{CO}_{2}$. Under a binocular microscope, the number of colonies, which consisted of not less than 50 cells, was counted. The result was expressed in the number of colonies per $1 \cdot 10^{6}$ bone marrow cells.

To assess the osteogenic potential of MIMSCs, the bone marrow cells of the 3rd passage were cultured in an osteoinductive medium consisting of DMEM with $1.0 \mathrm{~g} / \mathrm{L}$ glucose, $10 \%$ fetal calf serum (FCS), $100 \mathrm{nM}$ dexamethasone, $10 \mathrm{mM} \quad \beta$-glycerophosphate, $0.05 \mathrm{mM}$ L-ascorbate2-phosphate (all - Sigma, USA) [21]. After 21 days, the monolayer of cells was washed with phosphate buffered saline (PBS), fixed with 10 $\%$ paraformaldehyde solution, and then stained with $2 \%$ Alizarin Red S (Sigma, USA). Semiquantitative analysis of the mineralization degree of stained cultures was carried out by the colorimetric method according to C. Gregory [22]. The dye bound to the calcified extracellular matrix was extracted with acetic acid and $\mathrm{pH}$ was adjusted to 4.1 with ammonium hydroxide. The degree of staining was evaluated on Multiskan EX (Thermo Scientific, USA) microplate photometer at a wavelength of $405 \mathrm{~nm}$.

To assess the adipogenic potential of MIMSCs, bone marrow cells of the 3rd passage were cultured in an adipogenic differentiation medium consisting of DMEM with $4.5 \mathrm{~g} / \mathrm{L}$ glucose, $5 \%$ horse serum, $10 \%$ FCS, $1 \mu \mathrm{M}$ dexamethasone, $200 \mu \mathrm{M}$ indomethacin, $500 \mu \mathrm{M}$ isobutylmethylxanthine and $5 \mu \mathrm{g} / \mathrm{mL}$ insulin (all - Sigma, USA). After 14 days, the cultures were washed with PBS, fixed using $10 \%$ paraformaldehyde solution, and then stained with Oil Red 0 (Sigma, USA) to detect lipid inclusions [23]. Under the inverted microscope IX71 (Olympus, Japan), cells that contained and did not contain lipid droplets in 10 random fields of view were counted. The results were expressed as a percentage.

Immunomodulating effect of bone marrow MMSCs of the $3^{\text {rd }}$ passage on mitogen-stimulated proliferation of syngeneic murine splenocytes was studied in the phytohemagglutinin-induced lymphocyte blast transformation test using the MTT assay [24]. Splenocytes were incubated with $0.01 \mathrm{mg} / \mathrm{mL}$ phytohemagglutinin without and with the addition of MMSCs at different doses of $1.5 \cdot 10^{4}, 3.0 \cdot 10^{4}$ or $6.0 \cdot 10^{4}$ MMSCs per $10^{6}$ splenocytes for 72 hours. Two hours before the end of the incubation, $0.01 \mathrm{~mL}$ of $0.5 \%$ solution of MTT (3-(4,5-dimethylthiazole)-2,5-diphenyltetrazole bromide) was added, and at the end $-0.04 \mathrm{M}$ of $\mathrm{HCl}$ in isopropyl alcohol. The optical density of the supernatant was measured on Multiskan EX (Thermo Scientific, USA) microplate photometer at a wavelength of 492 $\mathrm{nm}$. The results were presented in arbitrary units of proliferation index (PI): $\mathrm{PI}=$ optical density of mitogen-activated splenocytes cultures + MMSCs / optical density of splenocytes cultures without MMSCs. For control sample $-\mathrm{PI}=$ optical density of mitogen-activated splenocytes cultures / optical density of splenocytes cultures without mitogen.

For estimation of thymulin effects in vitro, bone marrow-derived MMSCs of thymectomized mice were incubated with thymulin (Sigma, USA) at concentrations of $1 \mathrm{ng} / \mathrm{mL}$ and $10 \mathrm{ng} / \mathrm{mL}$ and analyzed their clonogenic potential. When studying the influence of the thymulin on directed differentiation, it was added at a concentration of $1 \mathrm{ng} / \mathrm{mL}$ at each change of differentiation medium. When studying the immunomodulatory properties of MMSCs, thymulin was added at a concentration of $1 \mathrm{ng} / \mathrm{mL}$ at each change of the nutrient medium. In all experiments, the values were 
compared with the control group - bone marrow MMSCs of thymectomized mice without in vitro incubation with thymulin.

Statistical analysis was carried out using the Statistica 7 software (StatSoft Inc., USA). The differences between the groups was assessed using Student's t-test. The results are presented as means and standard error of mean $(\mathrm{M} \pm \mathrm{m})$. The difference between the groups was considered statistically significant at a value of $p<0.05$ [25].

\section{RESULTS AND DISCUSSION}

EFFECT OF THYMECTOMY ON THE LEVEL OF THYMULIN IN FVB/N AND 129/SV MICE.

We established that the level of thymulin in control sham-operated FVB/N mice is higher than in 129/Sv mice and is $5.3 \pm 0.3$ and $4.3 \pm 0.2$ $\log _{2}$ titer $(p<0.05)$, respectively. In thymectomized mice of the studied strains, the hormone was not detected in the blood.

THE EFFECT OF THYMECTOMY ON THE BIOLOGICAL PROPERTIES OF

THE BONE MARROW-DERIVED MIMSCS OF FVB/N AND 129/SV MIICE.

Clonogenic potential of bone marrow progenitor cells. The number of nucleated cells in the bone marrow of the mice of the experimental groups of both strains did not differ significantly. Thus, the bone marrow nucleated cell count in sham-operated FVB/N mice was $14.1 \pm 2.5 \bullet 10^{6}$ cells, in $129 /$ Sv mice $12.8 \pm 3.8 \cdot 10^{6}$ cells. Thymectomy did not lead to statistically significant changes in this indicator: the number of nucleated cells in the bone marrow in FVB/N mice was $13.8 \pm 2.0 \cdot 10^{6}$ cells, in 129/ Sv mice $-12.9 \pm 1.4 \cdot 10^{6}$.

The amount of CFU-F in the bone marrow of control sham-operated FVB/N mice is higher $(p<0.05)$ than in $129 /$ Sv mice (Fig. 1). In thymectomized mice of both strains, the CFU-F number are less $(p<0.05)$ than in control groups (Fig. 1). The difference between the studied groups is more expressed in FVB/N mice (1.9 times) than in 129/Sv (1.4 times).

Therefore, the ability of bone marrow progenitor cells to colony formation in control sham-operated and thymectomized mice depends on their genotype. After the addition of thymulin at a concentration of $10 \mathrm{ng} / \mathrm{mL}$ in cell culture of thymectomized mice of both strains, the amount of CFU-F increases in comparison with bone marrow cells of thymectomized and thymectomized with the addition of thymulin at a concentration of $1 \mathrm{ng} / \mathrm{mL}$ (Fig.1).

The ability of the bone marrow MIMSCs to directed differentiation. In parallel with the study of bone marrow MMSCs ability to the directed differentiation, a characterization of the MMSCs phenotype was performed. Cultured bone marrow MMSCs of the 3rd passage of both mice strains express typical CD44, CD73, CD90, and Sca-1 markers and do not express the pan-leukocyte marker CD45 (Table 1).

It has been established that the osteogenic potential of bone marrowderived MMSCs in the control sham-operated FVB/ $\mathrm{N}$ mice is higher than in 129/Sv mice, while the adipogenic one is lower (Fig. 2, 3). After thymectomy, MMSCs differentiation in the osteogenic direction is observed in FVB/N mice, and in 129/Sv mice, there is its decrease (Fig. 2).

The ability of MMSCs to adipogenic differentiation decreases in thymectomized FVB/N mice and does not change in 129/Sv mice (Fig. 3). Thus, in mice, both intact and thymectomized, strain-dependent differences in the directed differentiation of bone marrow-derived MMSCs were revealed.

When evaluating the effect of thymulin in vitro on the osteogenic potential of bone marrow-derived MMSCs of thymectomized mice, its significant increase in 129/Sv mice and absence of changes in the FVB/N mice are shown (Fig. 2). The adipogenic differentiation rate, after incubation

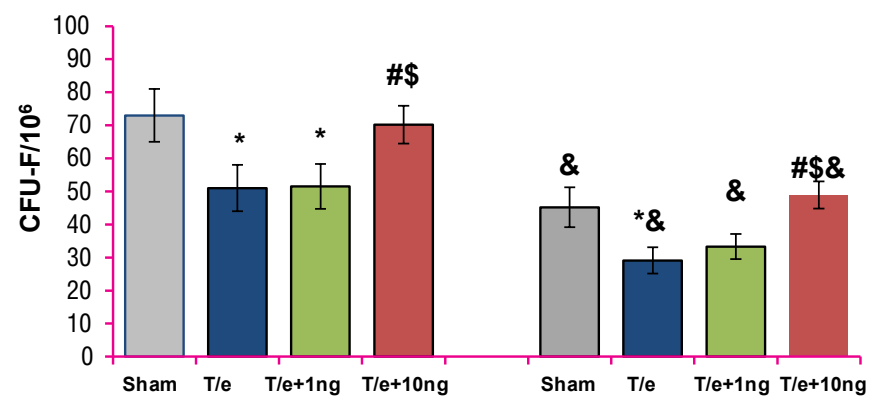

Fig. 1. Colony-forming activity of bone marrow-derived MMSCs of thymectomized FVB/N and 129/Sv mice after thymulin application in vitro, $\mathrm{M} \pm \mathrm{m}$; Sham - sham-operated mice; T/e - thymectomized mice, $\mathrm{T} / \mathrm{e}+1 \mathrm{ng}$ - thymectomized mice + thymulin at a concentration of $1 \mathrm{ng} / \mathrm{mL}$ in vitro, T/e+10 $\mathrm{ng}$ - thymectomized mice + thymulin at a concentration of $10 \mathrm{ng} / \mathrm{mL}$ in vitro.

Notes: ${ }^{*}-p<0.05$ compared with sham-operated mice; $\#-p<0.05$ compared with thymectomized mice; $\$-p<0.05$ compared with thymectomized + thymulin at a concentration of $1 \mathrm{ng} / \mathrm{mL}$ in vitro; $\&-p<0.05$ compared with FVB/N mice.

of MMSCs with thymulin, did not change in 129/Sv mice and was increased in FVB/N mice.

Immunomodulating effect of bone marrow-derived MIMSCs on mitogen-stimulated proliferation of splenocytes. Bone marrow-derived MMSCs of all the experimental groups show an immunosuppressive effect on the mitogen-activated proliferative response of splenocytes in MMT assay (Fig. 4, 5). Thus, bone marrow MMSCs of the control sham-operated FVB/N mice at doses of $1.5 \cdot 10^{4}, 3.0 \cdot 10^{4}$ and $6.0 \cdot 10^{4}$ cells decrease the lymphocyte blast transformation index by $3.7,4.5$ and 4.9 times, respectively, and the 129/Sv mice at the same doses - by 2.6, 2.7 and 3.6 times, respectively. In the thymectomized FVB/N mice, the rate of lymphocyte blast transformation at a dose of MMSCs $1.5 \cdot 10^{4}, 3.0 \cdot 10^{4}$ and 6.0.10 cells is increased to 5.2, 6.1 and 6.8 times (Fig. 4).

In the thymectomized 129/Sv mice, the immunosuppressive effect of MMSCs at doses of $1.5 \cdot 10^{4}, 3.0 \cdot 10^{4}$ and $6.0 \cdot 10^{4}$ cells decreases respectively to 2.3, 2.5 and 2.3 times (Fig. 5). At the same time, the lymphocyte blast transformation index in $129 / \mathrm{Sv}$ mice significantly exceeds those in FVB/N mice (Fig. 4, 5).

It was established that the proliferative potential of splenocytes in the lymphocyte blast transformation test did not change after co-culture with MMSCs of both mice strains, previously incubated with thymulin $(p>0.05)$.

Therefore, we have established the immunosuppressive effect of bone marrow-derived MMSCs in mice of both strains. In this case, strain-dependent differences in this effect are manifested in the degree of immunosuppression and after thymectomy, in the type of its changes. Thymulin in vitro is able to change the clonogenic and osteogenic potential of bone marrow-derived MMSCs of thymectomized mice of both strains, while the adipogenic potential was recovered in FVB/N mice, the immunosuppressive effect of MMSCs remained unchanged.

Thus, the results of our in vivo and in vitro studies have made it possible to establish a definite relationship between changes in the biological

\begin{tabular}{|l|c|c|c|c|c|}
\hline MICE STRAIN & CD44, \% & SCA-1, \% & CD73, \% & CD90, \% & CD45, \% \\
\hline FVB/N & $96.2 \pm 2.4$ & $97.0 \pm 1.9$ & $15.8 \pm 5.3$ & $96.2 \pm 1.2$ & $1.9 \pm 0.7$ \\
\hline $\mathbf{1 2 9} / \mathbf{S v}$ & $91.0 \pm 1.9$ & $81.5 \pm 0.4$ & $22.6 \pm 13.0$ & $95.1 \pm 1.3$ & $2.6 \pm 0.3$ \\
\hline
\end{tabular}


FVB/N

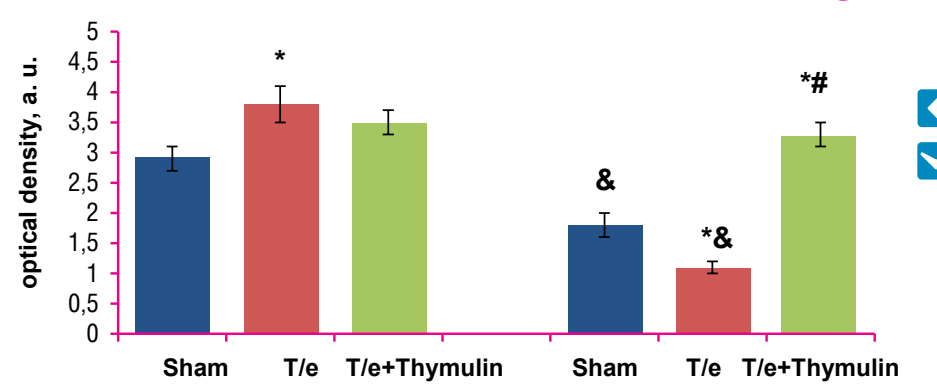

$129 / \mathrm{Sv}$
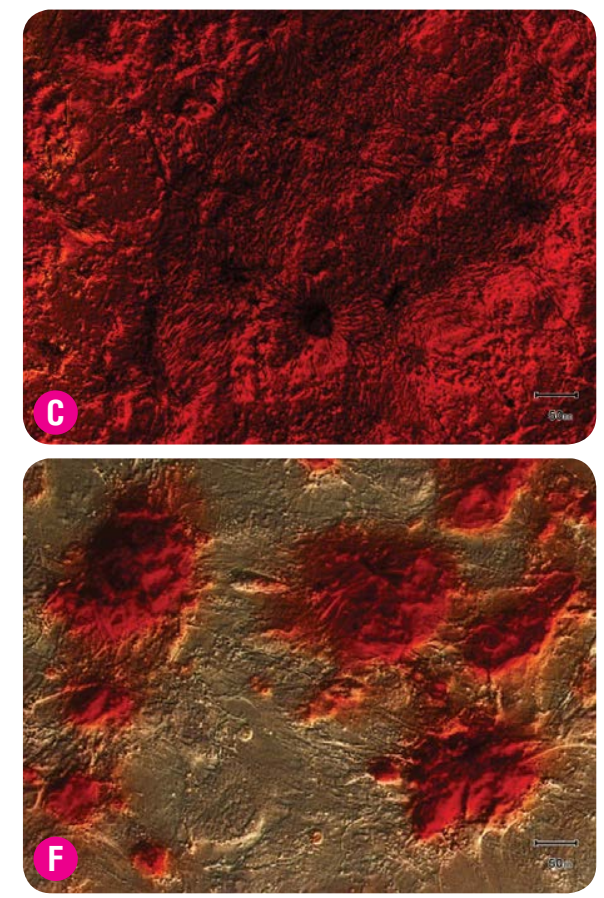

Fig. 2. Effect of thymectomy and thymulin in vitro on the directed osteogenic differentiation of the bone marrow-derived MMSCs of the FVB/N and 129/Sv mice. A - semi-quantitative analysis of the degree of mineralization of stained cultures (colorimetric method), $M \pm m$; Sham - sham-operated mice, T/e - thymectomized mice, T/e+Thymulin - thymectomized mice + thymulin at $1 \mathrm{ng} / \mathrm{mL}$ in vitro.
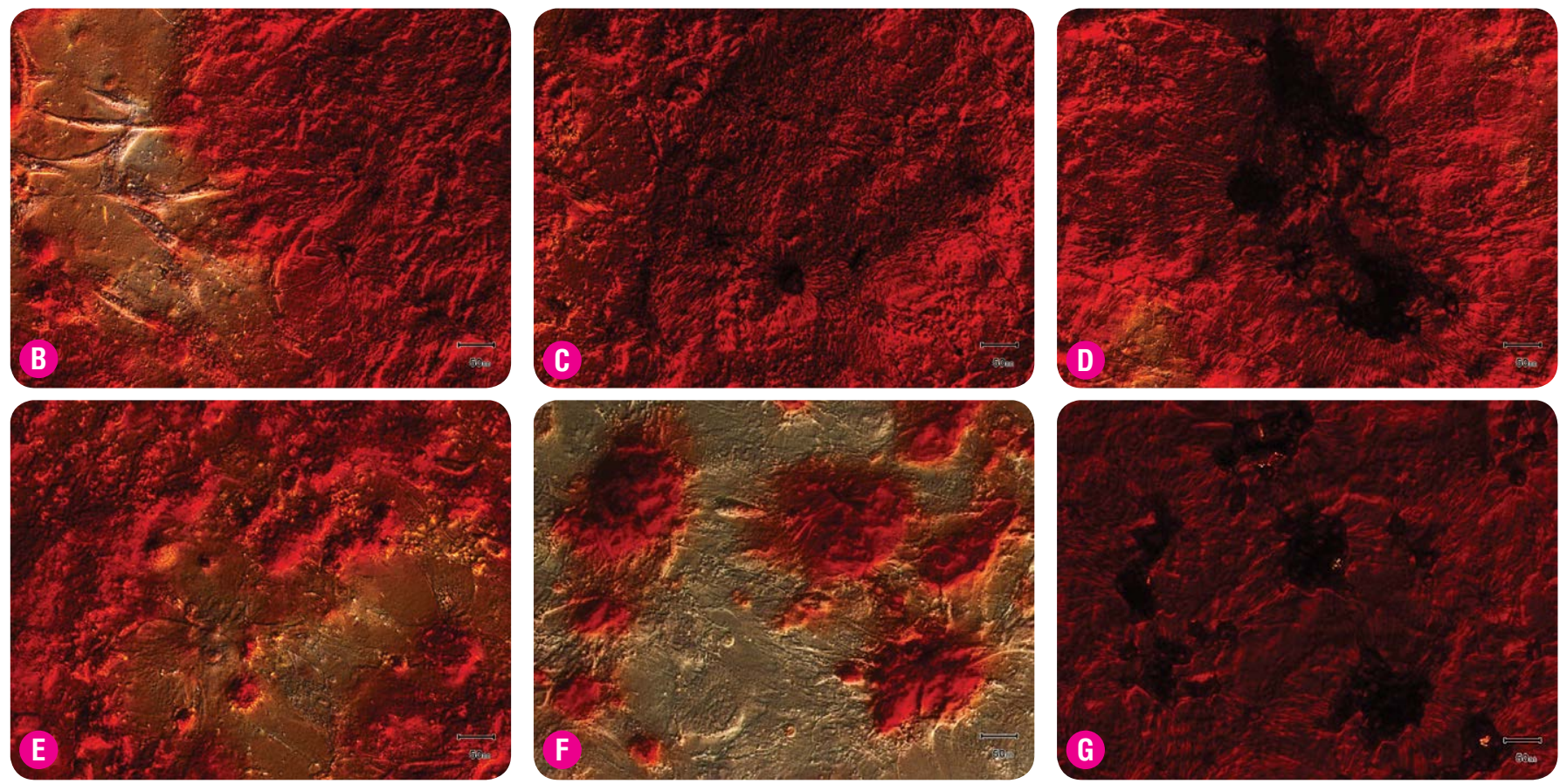

Notes: * $-p<0.05$ compared with sham-operated mice; \# - $p<0.05$ compared with thymectomized mice; \& $-p<0.05$ compared with FVB/N mice.

$B-G$ - the micrographs of the directly differentiated in the osteogenic medium bone marrow-derived MMSCS of FVB/N (B-D) and 129/SV (E-G) mice:

$B, E$ - sham-operated mice; C, F-thymectomized mice; $D, G$ - thymectomized mice + thymulin at $1 \mathrm{ng} / \mathrm{mL}$ in vitro; Alizarin Red $S$ staining, phase contrast.

properties of bone marrow-derived MMSCs and the endocrine function of the thymus, which exhibits strain-dependent features.

It was shown that in the control sham-operated FVB/N mice, the colony-forming ability of bone marrow cells significantly exceeds that of $129 / \mathrm{Sv}$ mice and at the same time is associated with a higher level of thymulin in blood. Recovery of thymectomized mice with a reduced ability of the bone marrow population to colony formation after incubation with thymulin may be associated with an increase in expression of growth factor cells under the influence of this hormone. Land et al. [26] have shown that in the culture of fetal lung tissue, thymulin at a dose of $1.0 \mathrm{ng} / \mathrm{mL}$ increases the expression of fibroblasts growth factors FGF9 and FGF10, which is associated with massive proliferation of undifferentiated mesenchymal tissue.

One of the main properties of MMSCs is their ability to differentiate into different cell types of connective tissue [27, 28]. In our work, we evaluated the ability of bone marrow-derived MMSCs of FVB/N and 129/ Sv mice to differentiate in the osteogenic and adipogenic directions. It was shown that the balance between these differentiation directions is controlled by cellular factors and can change in conditions of dysfunction of the immune system [13, 29]. Thus, in mice with age-related T-cell deficiency, the number of cells expressing osteoblast specific transcription factors Runx2 and DIx5, osteoblast markers, collagen and osteocalcin decreases in the bone marrow and, conversely, the number of cells expressing the adipospecific transcription factor PPARy2 increases, which stimulates differentiation of adipocytes and development of autocrine and paracrine factors inhibiting osteogenesis [29].

In our experiment, in sham-operated FVB/N mice with a higher level of thymulin in the blood, the differentiation of MMSCs was predominantly in an osteogenic direction, in contrast to 129/Sv mice, in which we observed a differentiation shift towards adipogenesis. According to Oksimets et al. [30], cytokines IL-1 $\beta$, IL-2, IL-6, IL-8, TNF-a, which are secreted by transplanted MMSCs, play an important role in regulation of osteogenesis in injured limbs. The involvement of transcription factor NF-KB in implementation of thymulin effect in tissues in vivo and in vitro has been shown by altering the synthesis of proinflammatory (TNF- $\alpha$, IL-1 $\beta$, IL-6) and anti-inflammatory cytokines (IL-10) [31].

It is also possible that differences in MMSCs differentiation potential of the studied control mice can be related to strain-dependent features of the functional state of the neuroendocrine system. For example, in FVB/N mice, the level of thyroxine (T4) in the blood is almost three times higher than that of 129/Sv mice, while in rats deficient in T4, the differentiation of MMSCs in the osteogenic direction is strongly inhibited [32, 33, 34]. It has been shown that melatonin stimulates differentiation of osteoblast precursors, increases osteoblast activity and expression of collagen type 1, osteopontin and osteocalcin [11, 35, 36]. According to our data, the level of melatonin in the blood of FVB/N mice [18] exceeds that of 129/Sv mice (unpublished data). 
FVB/N

$129 / \mathrm{Sv}$

A
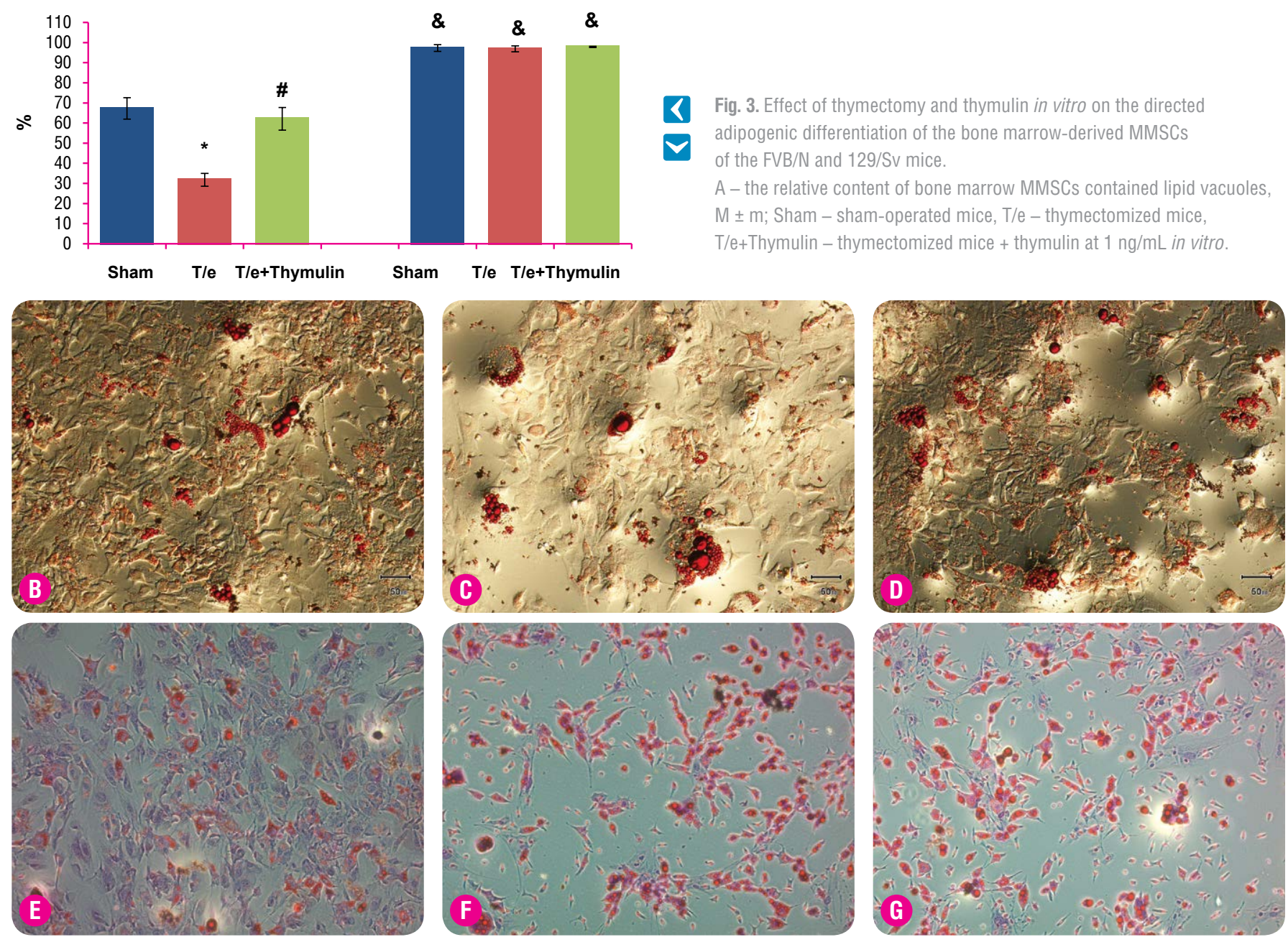

Notes: * $-p<0.05$ compared with sham-operated mice; \# - $p<0.05$ compared with thymectomized mice; \& $-p<0.05$ compared with FVB/N mice. $B-G$ - the micrographs of the directly differentiated in the adipogenic medium bone marrow-derived MMSCS of FVB/N (B-D) and 129/SV (E-G) mice:

$B, E$ - sham-operated mice; $C, F$-thymectomized mice; $D, G$ - thymectomized mice + thymulin at 1ng/mL in vitro; Oil Red 0 staining, phase contrast, $x 400$ ( $B, C, D$ ), $x 200(E, F, G)$.

The results of the experiments with the incubation of MMSCs of thymectomized 129/Sv mice with thymulin allowed to obtain a new understanding of possible ways of hormone effects on the reduced osteogenic potential of bone marrow-derived MMSCs. In our earlier studies, we showed that osteogenesis, reduced at thymic hormones (in particular, thymulin) deficiency, can be restored by injections of thymic bioactive factors [37].

At the same time, a sufficiently high degree of mineralization of the extracellular matrix of FVB/N mice MMSCs cultures is further enhanced after removal of the thymus and does not change after incubation with thymulin in vitro. It is known that the regulatory effect of thymus hormones on target cells depends on their initial state [38]. Therefore, we do not exclude the fact that the results obtained most likely reflect the straindependent features of MMSCs reaction to changes in the level of thymulin in the blood and in the cell culture media. Earlier we have already shown the difference in the response of bone marrow-derived MMSCs of FVB/N mice from other strains to the change in the level of thymulin in the blood under stress conditions [17]. According to Nikolskiy et al. [39], dysbalance and dysfunction of stromal cells (in particular, activation of lineage differentiation of MMSCs in the osteogenic direction) can be mediated by quantitative and functional disorders in the subpopulations of immune cells (thymocytes).

Under physiological conditions, T-lymphocytes play a protective role in the metabolism of bone tissue, and osteogenesis decreases in animals with a deficit of $\mathrm{CD} 4^{+}$and $\mathrm{CD} 8^{+} \mathrm{T}$ cells in bone marrow [13]. At the same time, dysbalance of $\mathrm{CD}^{+} / \mathrm{CD} 8^{+}$cells is observed in the bone marrow of thymectomized FVB/N mice, characterized by a significant decrease in the number of $\mathrm{CD}^{+}$cells and an increase in the number of $\mathrm{CD} 4^{+}$cells [10]. The shift toward enrichment of the bone marrow of such $\mathrm{CD}^{+}$mice is combined with cells with an increase in the differentiation of MMSCs in the osteogenic direction. It is shown that $\mathrm{CD} 4^{+} \mathrm{T}$ cells produce $\mathrm{IL}-17$, which is a powerful growth factor for MMSCs [13]. Simultaneous inhibition of adipogenic differentiation in thymectomized FVB/N mice gives us grounds for supposing that their MMSCs predominantly differentiates in the osteogenic direction, which explains the increased mineralization of the extracellular matrix of cell cultures.

The obtained results can indicate the prospects of using FVB/N and $129 /$ Sv mice, including thymectomized, to study the influence of factors with both suppressive and activating effects on the bone marrow osteogenic differentiation of MMSCs. In addition, the mice of these strains can be useful in studying the influence of different subpopulations of T-lymphocytes on the function of the bone marrow-derived MMSCs.

We also found that in the mice of both strains the bone marrow-derived MMSCs have an immunosuppressive effect on mitogen-activated T-lymphocytes. At the same time, the intensity of the MMSCs effect depends on the mice strain and is not related to the specific features of the proliferative potential of T-lymphocytes. From the literature it is known 


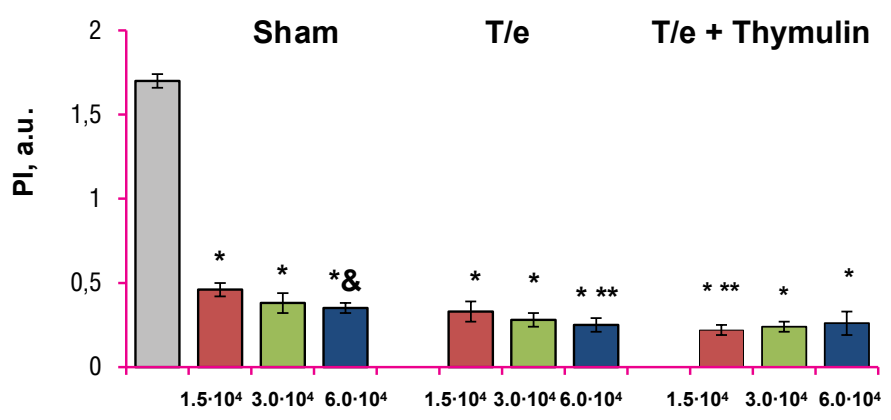

A Fig. 4. The proliferation index (PI) of FVB/N mice splenocytes after co-culture with bone marrow-derived MMSCs according to the MTT assay, $\mathrm{M} \pm \mathrm{m}$; Sham - sham-operated mice, T/e - thymectomized mice, T/e+Thymulin - thymectomized mice + thymulin at $1 \mathrm{ng} / \mathrm{mL}$ in vitro.

\author{
Notes: ${ }^{*}-p<0.05$ compared with PI of splenocytes (gray); \\ ${ }^{* *}-p<0.05$ compared with sham-operated mice; $\&-p<0.05$ \\ compared to the PI splenocytes when co-cultured with $1.5 \cdot 10^{4}$ MMSCs.
}

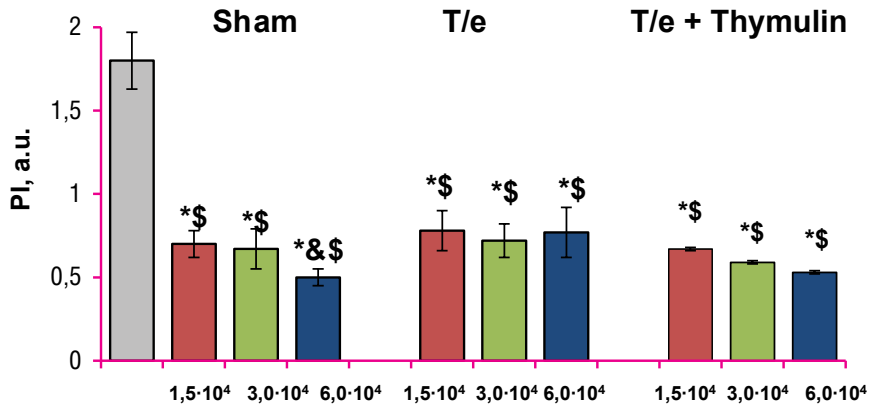

A Fig. 5. The proliferation index (PI) of 129/Sv mice splenocytes after co-culture with bone marrow-derived MMSCs according to the MTT assay, $\mathrm{M} \pm \mathrm{m}$; Sham - sham-operated mice, T/e - thymectomized mice, $\mathrm{T} / \mathrm{e}+$ Thymulin - thymectomized mice + thymulin at $1 \mathrm{ng} / \mathrm{mL}$ in vitro.

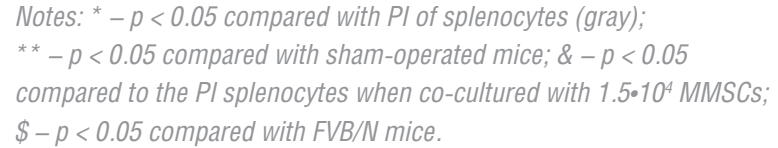

decrease in 129/Sv mice). Strain-dependent differences in the interaction of MMSCs and some hormones, in particular, the response of these cells to the effect of glucocorticoids, may also be important [44]. Earlier we showed an increase in the level of glucocorticoids in the blood of thymectomized mice, as well as the lack of their suppressor effect on cells and mediators of the immune system in FVB/N mice, in contrast to mice of other strains [17].

Thus, we have obtained data that prove the important role of the thymus in the manifestation of the biological properties of the bone marrow-derived MMSCs. In this case, the effect of thymus and its hormone thymulin on these cells depends on the genotype of the mice. The results obtained can be useful in the development of individualized cell therapy of damage of various genesis, in particular the musculoskeletal system, in conditions of dysfunction of central immune system.

\section{CONCLUSION}

1. The clonogenic potential, the ability to directed osteogenic and adipogenic differentiation, the immunosuppressive effect of the bone marrow-derived MMSCs of the FVB/N and 129/Sv mice are associated with the function of the thymus and change after thymectomy.

2. The possibility of a direct recovery effect of thymulin on the reduced clonogenic and osteogenic potential of the bone marrow-derived MMSCs of both mice strains and adipogenic potential of FVB/N mice is shown.

3. Immunodeficiency of a central genesis changes the biological properties of the bone marrow-derived MMSCs and can thus change the effectiveness of cell therapy with the application of bone marrow-derived MMSCs.

\section{REFERENCES}

1. Lotfinegar $P$, Shamsasenjian $K$, Movassaghpour $A$, et al. Immunomodulatory nature and site specific affinity of mesenchymal stem cells: a hope in cell therapy. Adv Pharm Bull. 2014; 4(1):5-13.

2. Kuroda Y, Kitada M, Wakao S, et al. Bone marrow mesenchymal cells: how do they contribute to tissue repair and they really stem cells? Arch Immunol Ther Exp. 2011; 59:369-378.

3. Orlic D, Kajstura J, Cimenti S. Bone marrow cells regenerate infarcted myocardium. Nature. 2011; 410:701-705.

4. Sekiya I, Larson BL, Vuoristo JT, et al. Adipogenic differentiation of human adult stem cells from bone marrow stroma (MSCs). J Bone Miner Res. 2004; 2:256-264.

5. Bommie F, Sung-No J. The Immunomodulatory Effects of Mesenchymal Stem Cells in Prevention or Treatment of Excessive Scars. Stem Cells International. 2016. 8 p. Available from: $h$ ttps:// dx.doi.org/10.1155/2016/6937976. 
6. Tyndall A, Uccelli A. Multipotent mesenchymal stromal cells for autoimmune diseases: teaching new dogs old tricks. Bone Marrow Transplant. 2009; 43(11):821-828.

7. Deshpande S, James AW, Blougha J, et al. Reconciling the effects of inflammatory cytokines on mesenchymal cell osteogenic differentiation. J Surg Res. 2013; 185(1):278-285. DOl:10.1016/j.jss.2013.06.063.

8. Lee EJ, Bajracharya $P$, Jang EJ, et al. Effect of sex steroid hormones on bovine myogenic satellite cell proliferation, differentiation and lipid accumulation in myotube. Asian-Aust J Anim Sci. 2010; 23(5):649-658.

9. Reggiani PC, Schwerdt Jl, Console GM, et al. Physiology and therapeutic potential of the thymic peptide thymulin. Curr Pharm Des. 2014; 20(29):4690-4696.

10. Labunets IF, Rodnichenko AYe, Vasyliev RG. Sposobnost' kletok-predshestvennits granulotsitov i makrofagov kostnogo mozga myshey raznykh liniy k obrazovaniyu koloniy in vitro pri izmenenii soderzhaniya timulina v organizme i v kul'ture kletok [Capacity of bone marrow granylocyte and macrophage precursors in mice of different strains for in vitro colony formation under changed thymulin level in the organism and cell cultures]. Genes\&Cells. 2017; 12(2):97-103. D0l: 10.23868/201707021. [In Russian]

11. Labunets IF, Rodnichenko AYe. Vliyanie melatonina i timulina na biologicheskie svoystva mul'tipotentnykh mezenkhimal'nykh stromal'nykh kletok i gemopoeticheskikh stvolovykh kletok kostnogo mozga myshey raznykh liniy [The influence of melatonin and thymulin on the biological properties of multipotent mesenchymal stromal cells and bone marrow hematopoietic stem cells of mice different strains]. Klitinna ta organna transplantologiya. - Cell and Organ Transplantology. 2017; 5(2):242. [In Russian]

12. Labunets IF. Epifiz i ritmy funktsiy immunnoy sistemy pri starenii. Eksperimental'noe issledovanie [Epiphysis and rhythms of immune system functions during aging. Experimental study]. Saarbrucken: LAP LAMBERT Academic Publishing, 2012. 133 p. [In Russian]

13. Di Rosa F. T-lymphocyte interaction with stromal, bone and hematopoietic cells in the bone marrow. Cell Biol. 2009; 87(1):20-29.

14. Ustymenko AM. Vpliv postnatal'noï timektomiï u mishey liniï CBA/Ca na klitini-poperedniki kistkovogo mozku i formuvannya kistki v zrilomu vitsi [Influence of postnatal thymectomy in CBA/Ca mice on bone marrow precursor cells and bone formation in adulthood: avtoref. dissert. ... Candidate of Biological Sciences]. Kyiv, 2006. 16 p. [In Ukrainian]

15. Anisimov VN. Molekulyarnye i fiziologicheskie mekhanizmy stareniya [Molecular and physiological mechanisms of aging]. Sankt-Peterburg: Nauka - Saint-Petersburg: Science, 2008. 434 p. [In Russian]

16. Peister A, Mellad JA, Larson BL, et al. Adult stem cells from bone marrow (MSCs) isolated from different strains of inbred mice vary in surface epitopes, rates of proliferation, and differentiation potential. Blood. 2004; 103:1662-1668.

17. Labunets IF, Kuchuk OV, Rodnichenko AE, et al. Geneticheskie osobennosti funktsional'nogo sostoyaniya immunnoy sistemy u intaktnykh myshey i v usloviyakh stressovykh vliyaniy [Genetic features of the functional state of the immune system in intact mice and under stressful influences]. Aktual'nye problemy akusherstva i ginekologii, klinicheskoy immunologii i meditsinskoy genetiki. Sbornik nauchnykh trudov. Kiev-Lugansk: Izdatel'stvo LugDMU - Actual problems of obstetrics and gynecology, clinical immunology and medical genetics. Collection of scientific papers. Kiev-Lugansk: Publishing house LugGMU. 2010; 19:271-281. [In Russian]

18. Labunets IF. The peculiarities of age-related changes in the cellular composition of bone marrow, pineal melatonin-forming function, and thymus endocrine function in mice of different strains. Adv Gerontol. 2014; 4(2):134-139.

19. Bach JF, Bach MA, Blanot D, et al. Thymic serum factor (FTS). Bull Inst Pasteur. 1978; 76:325-398.

20. Friedenstein AJ, Chailakhian RK, Lalykina KS. The development of fibroblast colonies in monolaier cultures of guinea pig bone marrow and spleen colonies. Cell Tissue Kinet. 1970; 3:393-403.

21. Li S, Mareddy J, Tan DM, et al. A minimal common osteochondrocytic differentiation medium for the osteogenic and chondrogenic differentiation of bone marrow stromal cells in the construction of osteochondral graft. Tissue engineering Part A. 2009; 15(9):2481-2490.

22. Gregory $C A$, Gunn WG, Peister A, et al. An alizarin red-based assay of mineralization by adherent cells in culture: comparison with cetylpyridinium chloride extraction. Anal Biochem. 2004; 329:77-84.

23. Fernando AA, Dominique B. Isolation, culture, and differentiation potential of mouse marrow stromal cells. Curr Prot Stem Cell Biol. 2008. DOl: 10.1002/9780470151808. sc02b03s7.

24. Mosman T. Rapid colorimetric assay for cellular growth and survival: application to proliferation and cytotoxicity assays. J Immunol Methods. 1983; 65(1):55-63.

25. Lakin GF. Biometriia [Biometrics]. Moscow: Vysshaia shkola; 1990. 352 p. [in Russian].

26. Land SC, Darakhshan F. Thymulin evokes IL-6-C/EBP $\beta$ regenerative repair and TNF-a silencing during endotoxin exposure in fetal lung explants. Am J Physiol Lung Cell Mol Physiol. 2004; 286:L473-L487.

27. Orlic D, Kajstura J, Cimenti S. Bone marrow cells regenerate infarcted myocardium. Nature. 2011; 410:701-705.

28. Sekiya I, Larson BL, Vuoristo JT, et al. Adipogenic differentiation of human adult stem cells from bone marrow stroma (MSCs). J Bone Miner Res. 2004; 2:256-264.

29. Pardo J, Schwerdt Jl, Reggiani PC, et al. Physiology, molecular biology and therapeutic potential of the thymic peptide thymulin. Physiol Mini Reviews. 2012; 6(1):212.

30. Oksimets VM. Rol' mezenkhimal'nykh stromal'nykh kletok v osteoimmunnykh protsessakh [Role of mesenchymal stromal cells in osteoimmune processes]. Ukraïns'kiy zhurnal klinichnoï ta laboratornoï meditsini - Ukrainian Journal of Clinical and Laboratory Medicine. 2011; 6(1):94-98. [In Russian]

31. Haddad JJ, Hanbali L. The anti-inflammatory and immunomodulatory activity of thymulin peptide is NF-kB dependent and involves the downregulation of I kB-a. Am J Med Biol Res. 2013; 1(2):41-49.

32. Boeloni J, Ocarino N, Goes A, et al. Osteogenic differentiation of bone marrow mesenchymal stem cells of ovariectomized and nonovariectomized female rats with thyroid dysfunction. Pathol Res Pract. 2013; 209(1):44-51.

33. Panchenko AV, Popovich IG, Trashko AP, et al. Biomarkers of aging, life span and spontaneous carcinogenesis in the wild type and HER-2 transgenic FVB/N female mice. Biogerontology. 2015. DOl: 10.1007/s10522-015-9611-y.

34. Anisimov VN, Popovich IG, Zabezhinski MA, et al. Sex differences in aging, life span and spontaneous tumorigenesis in 129/Sv mice neonatally exposed to metformin. Cell Cycle. 2015; 14(1):46-55.

35. Liu J, Huang F, He HW. Melatonin effects on Hard tissue: bone and tooth. Int J Mol Sci. 2013; 14:10063-10074.

36. Litovka IG, Mazepa-Kryzhanivska VA, Berezovsky VYa. Vpliv melatoninu na metabolizm kistkovoï tkanini. [Influence of melatonin on bone tissue metabolism]. Fiziologichniy zhurnal - Journal Physiological. 2014; 60(2):102-109. [In Ukrainian]

37. Butenko GM, Povoroznyuk VV, Labunets IF, et al. Vliyanie peptidnykh faktorov timusa i epifiza na strukturno-funktsional'noe sostoyanie kostnoy tkani pri starenii: eksperimental'no-klinicheskoe issledovanie [Influence of thymus peptide factors and epiphysis on the structural and functional state of bone tissue during aging: an experimental clinical study]. Probl Osteol. - Problems of Osteology. 2001; 4(3):4-10. [In Russian]

38. Immunobiologiya gormonov timusa [Immunobiology of thymus hormones]. Ed by. Grinevich YuA, Chebotarev DF. Kiev: Zdorov'e, 1989. 160 p. [In Russian]

39. Nikolskiy IS, Nikolskaya VV, Demchenko DL, et al. Potentiation of direct osteogenic differentiation of thymic multipotent stromal cells by prior co-cultivation with thymocytes. Cell and Organ Transplantology. 2016; 4(2):220-223. 
40. Di NM, Carlo-Stella C, Magni M, et al. Human bone marrow stromal cells suppress T-lymphocyte proliferation induced by cellular or nonspecific mitogenic stimuli. Blood. 2002; 99(10):3838-3843.

41. Le Blanc K, Tammik L, Sundberg D, et al. Mesenchymal stem cells inhibit and stimulate mixed lymphocyte cultures and mitogenic responses independently of the major histocompatibility complex. Scand J Immunol. 2003; 57(1):11-20.

42. Chamberlain G, Fox J, Ashton B, et al. Concise review: mesenchymal stem cells: their phenotype, differentiation capacity, immunological features, and potential for homing. Stem Cells. 2007; 25(11):2739-2749.

43. Kyurkchiev D, Bochev I, Ivanova-Todorova E, et al. Secretion of immunoregulatory cytokines by mesenchymal stem cells. World J Stem Cells. 2014; 6(5):552-570.

44. Stolzing A, Sethe S, Scutt AM. Stressed stem cells: temperature response in aged mesenchymal stem cells. Stem Cells Dev. 2006; 15:478-487.

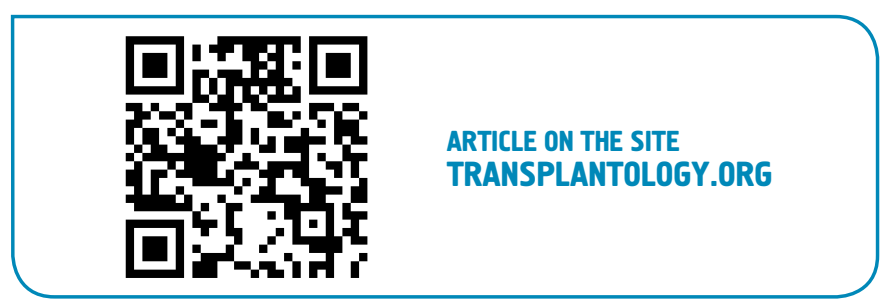

The authors indicate no potential conflicts of interest.

Received: April 02, 2018

Accepted: May 30, 2018 